\title{
旅游地农户生计资本评估与生计策略选择 一以海螺沟景区为例
}

\author{
刘俊, 张恒锦, 金朦朦, 李宁馨
}

(四川大学旅游学院, 成都 610065)

\begin{abstract}
摘要: 旅游地可持续发展需要重点关注当地居民生计的可持续。以海螺沟景区为案例地, 基 于可持续生计框架构建了适用的生计资本评估指标体系, 量化识别了景区农户可持续的生计 方式, 明确了影响两类脆弱性农户生计策略选择的主要因素。结果表明: 在研究区六种生计方 式中, 采用均衡兼收型和旅游主营型策略的农户其生计资本水平最高, 而传统务农型和务工型 农户生计资本水平最低。不同生计策略类型的农户在空间上集聚分布。缺乏金融资本是影响 传统务农型和务工型农户选择均衡兼收型生计策略的主要因素, 而物质资本和社会资本的缺 乏则对他们选择旅游主营型生计策略有显著的影响。此外, 海拔、距公路和核心景点的距离也 对农户生计策略的选择有重要影响。
\end{abstract}

关键词: 可持续生计;空间自相关;多元 logistic 回归;海螺沟景区

引导旅游地农户通过开展经营和提供服务参与旅游业被视为实现脱贫和乡村振兴的 有效方式 ${ }^{[1-3]}$ 。不过，居民除了参与旅游业外，还有其他的生计方式可以选择。例如，大 连金石滩旅游度假区的大部分居民从事房屋出租、做生意等其他非农型生计活动; 而在 秦岭北麓乡村旅游地, 仍以务工主导型农户居多 ${ }^{[4-5]}$ 。在这种情况下, 需要有科学、定量 的评估为居民生计策略选择提供依据。英国国际发展署（DFID）、联合国开发计划署 (UNDP)、美国援外汇款合作组织 (CARE) 等国际机构开发了生计资本评估的框架 ${ }^{[6]}$ 。 其中，英国国际发展署 DFID 提出的可持续生计框架运用最广 [7-9]。该评估框架建议从居民 家庭拥有的人力、自然、物质、金融和社会资本等方面全面评价居民生计活动的状况。 在评估框架的使用建议中，DFID指出由于不同地区具有一些特殊性，需要根据实际情况 对一些指标进行修改完善, 各指标的权重也需要进行调整 ${ }^{[10]}$ 。在掌握居民的家庭生计资 本禀赋的基础上，还应进一步明晰生计资本与居民生计策略选择的关系 ${ }^{[11-12]}$ 。

现有研究认为, 识别影响生计策略选择的因素是引导居民转换生计策略的关键 ${ }^{[13-14]}$,

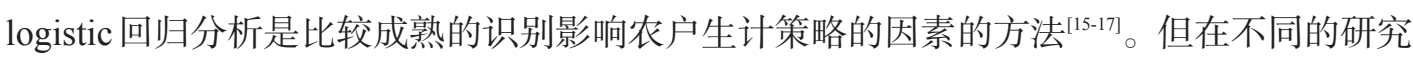
案例区，影响居民生计策略选择的生计资本因素有较大的差异 ${ }^{[18-19]}$ 。例如，在武陵源风景 名胜区，影响当地两类居民选择旅游型生计策略的显著性资本因素是人力资本和金融资 本，但对新疆喀纳斯生态旅游景区农牧民而言，金融资本则对牧民参与旅游业作用不显 著。此外，居民点空间布局的差异往往也对居民的生计状况有着决定作用 ${ }^{[20-21]}$, 但相关文 献更注重从省域市县尺度去研究贫困山区农户的生计资本空间格局 ${ }^{[22]}$, 而基于微观尺度

收稿日期：2019-03-21；修订日期：2019-05-30

基金项目：国家自然科学基金项目（41771163); 四川省重点研发项目（2018SZ0373); 四川大学创新火花项目库 (2018HHS-44)

作者简介：刘俊（1979- ), 男，四川乐山人，博士，教授，博士生导师，研究方向为可持续旅游。

E-mail: liujun_igsnrr@126.com 
分析生计策略的空间分布特征并探究居民点所处地形、空间距离因素对旅游地生计选择 影响的研究并不多见。在探究生计资本与生计策略关系时，也需要更细致地划分类型才 能全面了解旅游地不同特征类型农户的生计资本现状，有效甄别出生计脆弱性农户，提 出更精准的生计优化策略。

为此，本文借鉴可持续生计框架，以生态环境脆弱、旅游发展历史悠久的海螺沟景 区为案例地，基于更细分的农户策略类型量化分析景区农户生计资本水平，识别高水平 生计策略并探究不同生计策略的空间分布特征，利用多元 logistic 回归重点分析两类生计 脆弱性农户向高水平生计策略转化的影响因素，以期为旅游地居民选择可靠的生计策 略、实现生计策略转换提供科学依据。

\section{1 研究方法与数据来源}

\section{1 研究区概况}

海螺沟景区位于四川省甘孜藏族自治州泸定县境内（图 1)，地理坐标介于 $101^{\circ} 52^{\prime}$ $49^{\prime \prime} \sim 102^{\circ} 10^{\prime} 45^{\prime \prime} \mathrm{E} 、 29^{\circ} 29^{\prime} 30^{\prime \prime} \sim 29^{\circ} 39^{\prime} 20^{\prime \prime} \mathrm{N}$ 之间。地处四川盆地与青藏高原的过渡地带和横 断山脉最高峰贡嘎山东坡，是集亚洲东部最低海拔低纬度的现代海洋性冰川、生态完整 的原始森林、珍稀动植物和高温温泉群为一体的综合型旅游胜地。作为国内老牌景区之 一，海螺沟景区自 1987 年开营以来，相继被评为“国家级风景名胜区” “国家级森林公 园” “国家生态旅游示范区” 和 “国家 $5 \mathrm{~A}$ 级景区”，成为国内游客和东南亚游客的重要旅 游目的地。

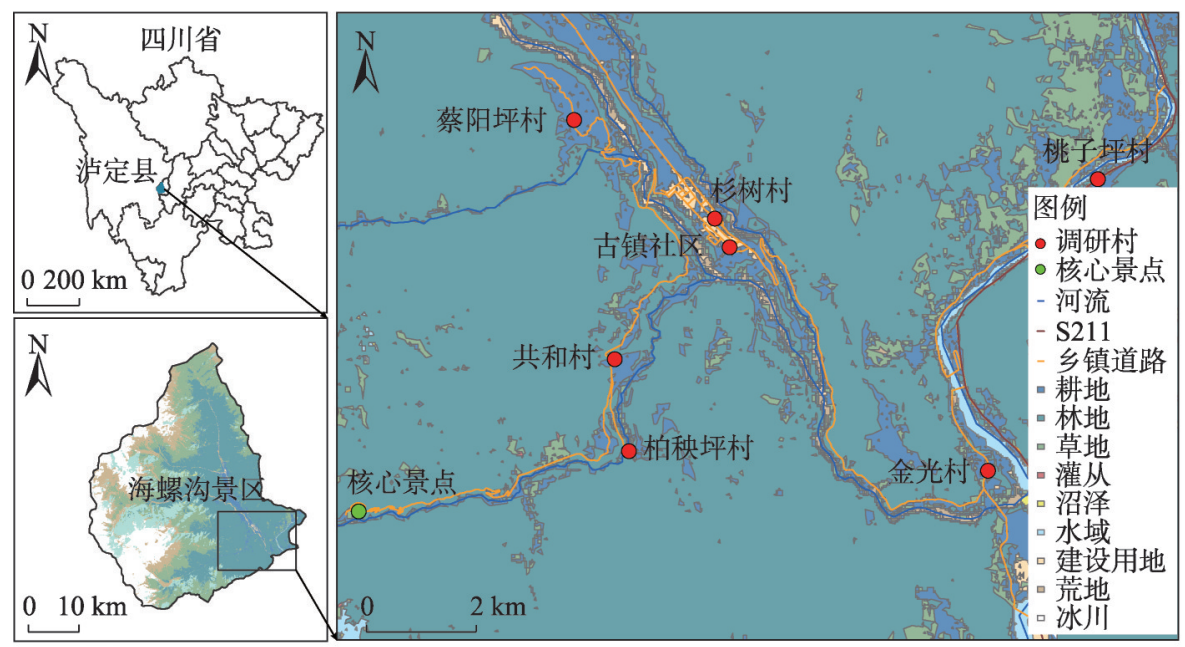

图 1 研究区区位示意

Fig. 1 Location of the study area

在行政规划上，海螺沟景区归属贡嘎山海螺沟风景区管理局，现辖乡镇磨西镇和新 兴乡，辖区面积 $906.13 \mathrm{~km}^{2}$ ，常住总人口 1.5 余万人。 2015 年海螺沟景区接待游客 125.98 万人次，同比增长 $36.19 \%$ ，旅游综合收人 12.47 亿元，同比增长 $130.93 \%$ 。在旅游的影响 下，海螺沟实现地区生产总值 5.32 亿元，完成固定资产投资 4.61 亿元 ${ }^{1}$ 。

(1) 研究区背景资料从磨西镇政府部门、海螺沟景区管理局等单位收集的二手统计数据得来。 
当地农户的生计策略也随着旅游发展而发生着改变。除了传统的生计方式外，开客 栈餐馆、经营温泉洗浴、乡村运输、园艺修剪、抬滑竿、景区售票等多样化的非农生计 活动成为越来越多家庭的选择。但同时，海螺沟景区农户仍面临着生态环境脆弱，自然 灾害频发等生计风险威胁, 这给当地农户生计和政府扶贫工作带来了挑战。因此, 选择 海螺沟景区作为案例地，具有较高的现实意义和代表性。

\section{2 数据来源}

本文研究数据主要包括三个部分：一是海螺沟景区管理局、海螺沟景区所辖乡镇收 集的自然和社会经济统计资料，二是人户问卷调查数据及半结构访谈信息，三是研究区 高清影像资料及利用便捷式GPS采集的调研户位置信息。

本文以海螺沟景区重要的旅游接待功能区磨西镇为重点调查区域, 由南向北选取金 光村、柏秧坪村、共和村、古镇社区、杉树村、桃子坪村和蔡阳坪村共 7 个调研村，每 村随机抽取 25 35 个样本进行人户调查。其中，问卷调查内容包括自然资本（调查户的 耕地播种面积和林地播种面积）、物质资本（房屋面积与类型、耐用消费品数量）、金融 资本（家庭年现金收人、收人来源构成、借贷款机会）、人力资本（家庭人口、性别与年 龄构成、劳动力情况、成员受教育程度)、社会资本（技能培训机会、参与社区组织状 况、亲属中是否有村干部）和农户的生计活动情况。半结构式访谈主要针对当地旅游经 营户、乡镇村委工作人员、海螺沟景区管理局人员，访谈内容涉及对当地旅游与经济发 展状况的感知与建议、家庭生计活动变迁等。

在具体应用上，利用 ArcGIS 10.2 软件从 DEM 高程数据中提取了农户居住点的海拔 高度、坡度, 并利用从网上获取的 Google Earth 影像资料中线状道路、调研获取的售票 中心和景区一号营地经纬度, 测算了居民点距最邻近公路的垂直最短距离（即公路距 离）、距海螺沟景区售票中心的最短直线距离（即售票中心距离）和距海螺沟核心景点一 号营地的最短直线距离 (即景点距离), 最后结合线状水系和土地利用等数据, 对研究结 果进行空间可视化处理。为了得到更好的问卷结果，调研组首先于 2018 年 3 月 1 日至 3 月 4 日在海螺沟景区的古镇社区进行了预调研。基于预调查的资料收集情况，完善了调查 问卷的设计，又于 2018 年 4 月 15 日至 22 日再次进行问卷调查和访谈，每户调查时间约 $35 \sim 0$ 分钟, 调查对象优先选择户主。最终共发放了 175 份问卷, 其中有效回收 160 份, 调查的有效率为 $91.42 \%$ 。

\section{3 研究方法}

\subsection{1 农户类型划分}

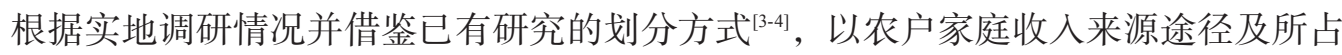
比例、主要劳动力投人方向为依据（表 1), 将研究区农户划分为以参与传统务农型、务 工型、公职收人型、旅游主营型、其他商贸型、均衡兼收型等六种生计策略。

\subsection{2 生计资本评价指标体系}

在 DFID 可持续生计框架中，由人力资本、自然资本、物质资本、金融资本和社会资 本构成的生计资本是这一框架核心，也是家庭拥有的选择机会、采用的生计策略和所处 风险环境的基础。本文依据该可持续生计框架并借鉴国内外学者关于生计资产的量化分 析研究 ${ }^{[23-25]}$, 结合实际情况, 构建了适用于海螺沟景区农户可持续生计的 13 项生计资本 评价指标，并用熵值法赋子指标权重（表2）。

\subsection{3 农户生计资本测算}

首先采用极值法对原始数据进行无量纲标准化处理，根据上述可持续生计资本各指 
表 1 农户生计策略类型及划分依据

Table 1 Types of households' livelihood strategies and their classification basis

\begin{tabular}{|c|c|c|c|c|}
\hline \multirow{2}{*}{ 农户类型 } & \multicolumn{2}{|c|}{ 划分依据 } & \multirow{2}{*}{ 样本数/个 } & \multirow{2}{*}{ 占样本量比 $/ \%$} \\
\hline & 收人来源 & 劳动力投人 & & \\
\hline 传统务农型 & 务农收人 $\geqslant 60 \%$ & 种植及养殖活动 & 22 & 14 \\
\hline 务工型 & 务工收人 $\geqslant 60 \%$ & 本地及外地打工 & 63 & 39 \\
\hline 旅游主营型 & 旅游服务经营收人 $\geqslant 60 \%$ & 旅馆/餐饮/温泉等旅游经营活动 & 25 & 16 \\
\hline 其他商贸型 & 其他个体经营收人 $\geqslant 60 \%$ & 日货/五金/运输等个体经营活动 & 24 & 15 \\
\hline 公职收人型 & 政府事业单位收人 $\geqslant 60 \%$ & 政府事业单位任职 & 5 & 3 \\
\hline 均衡兼收型 & 非农混合收人 $\geqslant 60 \%$ & 均衡参与务工/商品服务经营等 & 21 & 13 \\
\hline
\end{tabular}

表 2 海螺沟景区农户生计资本评价指标及权重

Table 2 Evaluation index and weight of households' livelihood capital in Hailuogou scenic area

\begin{tabular}{|c|c|c|c|c|}
\hline 一级指标 & 二级指标 & 符号 & 权重 & 指标说明 \\
\hline \multirow[t]{2}{*}{ 自然资本 $(N)$} & 耕地资源 & $N 1$ & 0.327 & 户均耕地播种面积 $/ \mathrm{hm}^{2}$ \\
\hline & 林地资源 & $N 2$ & 0.673 & 户均林地播种面积 $/ \mathrm{hm}^{2}$ \\
\hline \multirow[t]{2}{*}{ 物质资本 $(P)$} & 房屋情况 & $P 1$ & 0.333 & $\begin{array}{l}\text { 采用房屋面积和房屋类型两个指标 } \\
\text { 土木房 }=0.25 \text {; 砖木房 }=0.5 \text {; 砖混房 }=0.75 \text {; 混凝土房 }=1 \\
\text { 房屋面积 } 0 \sim 100 \mathrm{~m}^{2}=0.2 ; 100 \sim 200 \mathrm{~m}^{2}=0.4 ; 200 \sim 400 \mathrm{~m}^{2}= \\
0.6 ; 400 \sim 600 \mathrm{~m}^{2}=0.8 ; 600 \mathrm{~m}^{2} \text { 及以上 }=1\end{array}$ \\
\hline & 耐用消费品数量 & $P 2$ & 0.667 & 家庭拥有家用电器、交通工具、农机具的数量 \\
\hline \multirow[t]{3}{*}{ 金融资本 $(F)$} & 家庭年现金收人 & $F 1$ & 0.455 & 家庭年现金收人/万元 \\
\hline & 收人来源种类数 & $F 2$ & 0.486 & 户均现有生计活动种类数 \\
\hline & 获得借贷款机会 & $F 3$ & 0.059 & $\begin{array}{l}\text { 包括银行贷款、亲朋借款、政府无偿捐助 } \\
\text { 无 }=0 \text {; 能够获得 } 1 \text { 种 }=0.5 ; \text { 能够获得 } 2 \text { 种及以上 }=1\end{array}$ \\
\hline \multirow[t]{3}{*}{ 人力资本 $(H)$} & 户均家庭人口数 & $H 1$ & 0.294 & 户均家庭人口数 \\
\hline & 家庭整体劳动力 & $H 2$ & 0.352 & 非劳动力 $=0$; 半劳动力 $=0.5$; 全劳动力 $=1$ \\
\hline & 成员受教育程度 & $H 3$ & 0.354 & $\begin{array}{l}\text { 文盲 }=0 ; \text { 小学 }=0.25 ; \text { 初中 }=0.5 ; \\
\text { 高中 }=0.75 ; \text { 大专及以上 }=1\end{array}$ \\
\hline \multirow[t]{3}{*}{ 社会资本 $(S)$} & 获得技能培训机会 & $S 1$ & 0.480 & 有 $=1 ;$ 无 $=0$ \\
\hline & 参与社区组织状况 & $S 2$ & 0.108 & 极少参加 $=0$; 有时参加 $=0.5$; 经常参加 $=1$ \\
\hline & 亲属是否有村干部 & $S 3$ & 0.412 & 3 代直系亲属中是否有乡镇、村干部: 有 $=1$; 无 $=0$ \\
\hline
\end{tabular}

标的标准化值和权重，计算出农户所拥有的五种生计资本值 ${ }^{[6-27]}$ 。不同类型农户的五大生 计资本值和资本总值为该类样本户的平均值。设生计资本总值为 $T$, 计算公式为 ${ }^{[26]}$ :

$$
T=\sum_{i=1}^{5} \sum_{j}^{n} W_{i j} \times I_{i j}
$$

式中: $W_{i j}$ 为第 $i$ 种生计资本的第 $j$ 个评价指标的权重; $I_{i j}$ 为第 $i$ 种生计资本第 $j$ 个评价指标 的标准化值。

\subsection{4 全局空间自相关分析}

全局空间自相关描述了地理要素属性值在整个区域内的整体性空间分布状况，可以 判断该属性值在整个空间中是否存在空间集聚 ${ }^{[28]}$ 。本文采用全局 Moran's $I$ 指数来测度研 究区农村居民点生计资本值和生计类型的空间自相关程度，公式为 ${ }^{[29]}$ : 


$$
I=\frac{n}{S_{0}} \times \frac{\sum_{i=1}^{n} \sum_{j=1}^{n} W_{i j} \times\left(x_{i}-\bar{x}\right) \times\left(x_{j}-\bar{x}\right)}{\sum_{i=1}^{n}\left(x_{i}-\bar{x}\right)^{2}}
$$

式中： $x_{i}$ 为第 $i$ 空间单元的属性值; $W_{i j}$ 为区域空间权重矩阵，区域空间相邻为 1 , 不相关 为 $0 ; S_{0}$ 为空间权重矩阵所有元素之和; $\bar{x}$ 为所有属性值的平均数。当 Moran's $I$ 显著为 正时，表明属性值在空间上表现为显著集聚；当Moran's $I$ 显著为负时，属性值在空间 上则呈现分散格局; 当Moran's $I$ 接近期望值时，属性值呈随机分布格局。当 $Z$ 值 $>1.96$ 或 $Z$ 值 $<-1.96 （ \alpha=0.05 ）$ 时，拒绝原假设，表明农户生计资本值和生计类型在空间上具 有较显著的空间自相关性。

\subsection{5 多元 Logistic 回归模型}

为了确定影响旅游地不同类型农户选择高水平生计策略的影响因素及具体影响程 度，本文运用SPSS 21.0 建立了生计资本、空间特征要素与农户生计策略的多元 Logistic 回归模型。设无序多分类的被解释变量即农户的生计策略 $y=\left(y_{1}, y_{2}, y_{3}, y_{4}, y_{5}\right)$ ，分别代表 “传统务农型策略” “务工型策略” “旅游主营型策略” “其他商贸型策略”和“均衡兼收 型策略” (由于采取以公职收人型为主要策略的农户样本数量较少, 故不纳人分析中), $y$ 的取值范围为 $[1,5]$, 并将 $y_{k}=\left(y_{1}, y_{2}\right)$ 分别作为参照对象。设解释变量 $x=\left(x_{1}, x_{2}, \cdots\right.$, $\left.x_{m}\right), m$ 的取值范围为 $[1,10], x_{1} \sim x_{5}$ 分别代表农户的五类生计资本， $x_{6} \sim x_{10}$ 分别代表海拔、 坡度、公路距离、售票中心距离、景点距离。则相应的多元Logistic 回归模型如下所示:

$$
y_{l}=\ln \left[\frac{P_{y_{t}}}{P_{y_{k}}}\right]=\beta_{0}+\sum_{i=1}^{m} \beta_{i} \times x_{i}
$$

式中： $P_{y_{t}}$ 为事件 $y_{1}$ 发生的概率; $P_{y_{k}}$ 为参照对象 $y_{k}$ 的发生概率; $\beta_{0}$ 为截距; $\beta_{i}$ 为 $x_{i}$ 的待 估计参数，表示对应自变量一个单位的变化所导致的因变量的变化。若待估计系数大于 0 （或小于 0 ），表示在其他变量保持不变时，农户选择某类生计策略的发生率随对应自 变量的增加（减少）而增加（减少） ${ }^{[14]}$ 。

\section{2 结果分析}

\section{1 不同生计策略类型农户及其基本特征}

目前，海螺沟景区农户的生计策略仍以务工型为主，该类型农户占 39\%；其次是旅 游主营型和其他商贸型，选择该类生计策略的农户分别占 $16 \%$ 和 $15 \%$ ；依靠自然资源从 事种植和养殖活动的传统务农型农户近年来由于旅游开发占用耕地、退耕还林以及生计 资本发生变化等原因，数量逐渐减少，占总样本量的 $14 \%$ 。六类生计策略农户的基本特 征如下 (表 3):

研究区传统务农型农户主要依靠种植玉米、小麦等经济作物，白菜、青果等果蔬及 养殖猪、牛等牲畜为主要收人，户均家庭年现金收人和生计多样性指数最低，平均家庭 房屋面积为 $156.18 \mathrm{~m}^{2}$, 耐用消费品仅有 4.18 件，但耕地林地播种面积相对最多。务工型 农户主要包括建筑工地打工、餐馆酒店服务、社区卫生及治安服务等，该类农户家庭年 现金收人较低但家庭人口数量较多。公职收人型农户的主要家庭收人来源于政府等事业 单位任职，家庭年现金收人处于中等水平。其他商贸型农户主要依靠经营杂货铺、五金 钢材、理发店、乡村运输等与旅游没有直接关系的、以满足当地人日常生活所需的经营 
表 3 六类生计策略农户的基本特征

Table 3 Basic characteristics of households with six livelihood strategies

\begin{tabular}{|c|c|c|c|c|c|c|}
\hline 农户类型 & 传统务农型 & 务工型 & 公职收人型 & 旅游主营型 & 其他商贸型 & 均衡兼收型 \\
\hline 各类农户占比/\% & 14 & 39 & 3 & 16 & 15 & 13 \\
\hline 生计多样性指数 ${ }^{\mathrm{a}}$ & 1.23 & 1.79 & 2 & 1.52 & 1.79 & 3.05 \\
\hline 户均家庭人口数/人 & 3.64 & 4.24 & 3.2 & 4.36 & 3.92 & 4.48 \\
\hline 户均耕地播种面积 $/ \mathrm{hm}^{2}$ & 0.18 & 0.14 & 0.03 & 0.09 & 0.05 & 0.07 \\
\hline 户均林地播种面积 $/ \mathrm{hm}^{2}$ & 0.18 & 0.09 & 0.00 & 0.07 & 0.01 & 0.09 \\
\hline 家庭房屋面积/m² & 156.18 & 268.38 & 156.20 & 517.84 & 396.42 & 558.33 \\
\hline 耐用消费品数量/件 & 4.18 & 6.21 & 6.80 & 15.72 & 6.25 & 15.29 \\
\hline 户均年现金收人/万元 & 1.71 & 4.25 & 7.37 & 9.18 & 10.15 & 10.16 \\
\hline 农业收人/万元 & 1.44 & 0.38 & 0.04 & 0.42 & 0.04 & 0.91 \\
\hline 务工收人/万元 & 0.23 & 3.63 & 1.78 & 0.32 & 0.77 & 2.40 \\
\hline 公职收人/万元 & 0 & 0 & 5.55 & 0.36 & 0.16 & 1.64 \\
\hline 旅游收人/万元 & 0 & 0.04 & 0 & 8 & 0.48 & 2.68 \\
\hline 其他经营收人/万元 & 0.05 & 0.2 & 0 & 0.08 & 8.71 & 2.52 \\
\hline
\end{tabular}

注: $\mathrm{a}$ 为生计多样性指数, 对家庭从事的每种生计活动赋值为 1 , 如某个家庭从事两种生计活动, 则其多样化指数 值为 2 。

活动, 收人来源相对稳定, 户均家庭年收人较高, 但耕林地播种面积很少, 分别为 0.05 $\mathrm{hm}^{2}$ 和 $0.01 \mathrm{hm}^{2}$, 户均家庭耐用消费品数量也只有 6.25 件。

研究区旅游主营型农户从事旅馆、餐饮、农家乐、旅游特产品、温泉洗浴等旅游经 营活动，户均家庭年现金收人 9.18 万元，耐用消费品高达 15.72 件。均衡兼收型农户多样 化参与商品服务经营、旅游经营、政府事业单位任职、打工等活动，不仅家庭耐用消费 品（15.29件）和房屋面积 $\left(558.33 \mathrm{~m}^{2}\right)$ 处于较高水平, 收人来源也最为丰富均衡, 平均 每户从事三种以上的生计活动，户均家庭年现金收人高达 10.16 万元。

\section{2 研究区各类型农户的可持续生计资本状况}

通过原始数据的标准化处理和熵值赋权法，测算出研究区各类型农户的生计资本量 化值, 可直观反映出海螺沟景区农户生计资本现状，判定不同生计策略类型农户其生计 脆弱性的强弱 ${ }^{[30]}$ 。生计资本水平越高，该类型农 户应对生计风险和选择可持续生计的能力越强。 结合图 2 结果可看出, 研究区六类农户的生计资 本水平有着显著差异。总的来看, 生计资本水平 由高到低依次为: $T e$ 均衡兼收型 (2.158) $>T c$ 旅 游主营型 (1.872) $>T h$ 公职收人型 $(1.420)>T d$ 其他商贸型（1.381）> Tb 务工型（1.353）> Ta传 统务农型（1.055）。

研究区生计资本水平最高, 脆弱性较低是均 衡兼收型和旅游主营型农户。从五大生计资本值 来看（表 4)，均衡兼收型农户和旅游主营型农户 拥有相对最高的社会资本、人力资本和物质资 本，且均衡兼收型农户的金融资本最丰富。结合

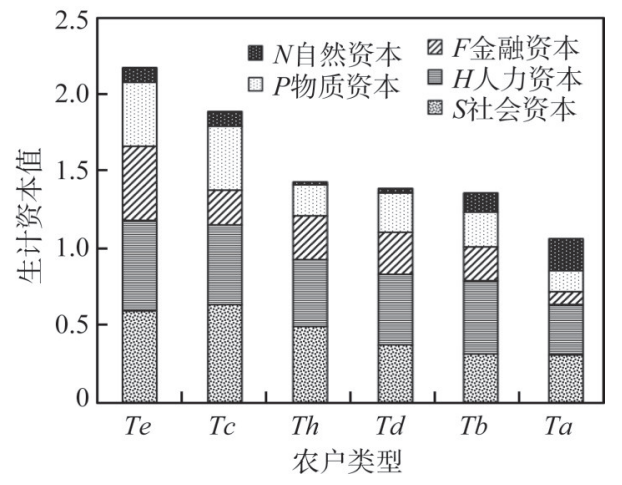

图 2 农户生计资本

Fig. 2 Column diagram of households' livelihood capital 
表 4 不同类型农户生计资本量化值

Table 4 The quantized livelihood capital values of different types of households

\begin{tabular}{ccccccc}
\hline 农户类型 & $N$ 自然资本 & $P$ 物质资本 & $F$ 金融资本 & $H$ 人力资本 & $S$ 社会资本 & 生计资本总指数 \\
\hline$T e$ & 0.094 & 0.413 & 0.479 & 0.583 & 0.590 & 2.158 \\
$T c$ & 0.092 & 0.413 & 0.222 & 0.517 & 0.629 & 1.872 \\
$T h$ & 0.015 & 0.201 & 0.282 & 0.435 & 0.487 & 1.420 \\
$T d$ & 0.032 & 0.253 & 0.272 & 0.454 & 0.371 & 1.381 \\
$T b$ & 0.129 & 0.224 & 0.217 & 0.470 & 0.314 & 1.353 \\
$T a$ & 0.207 & 0.132 & 0.087 & 0.321 & 0.308 & 1.055 \\
\hline
\end{tabular}

实地调研情况，这两类农户往往获得技能培训和贷款的机会更多、社会关系更好，并且 他们的家庭规模大、劳动力素质偏高，固定资产数量更多。这让他们有足够的人力物力财 力开展多种经营活动来增加家庭收人，提高抵御风险的能力，从而实现生计的可持续性。

生计水平较低、脆弱性较高的是公职收人型农户和其他商贸型农户。公职收人型农 户由于家庭主要劳动力在政府或事业单位任职, 拥有较高的学历和更广泛的社会联系, 但该类农户的自然资本和物资资本却相对较少，限制了生计资本的可持续水平。其他商 贸型农户的家庭年现金收人虽然相对较高，但家庭收人来源和固定资产较少，贷款机会 较低，又因为早期旅游开发成为失地农民，降低了自然资本储量，导致该类型农户的总 体可持续生计水平较低, 生计脆弱性较高。

而研究区生计水平最差、脆弱性最高的是传统务农型和务工型农户。就务工型农户 而言, 由于海螺沟当地的务工岗位较少且多以短工为主，导致选择该类生计策略的农户 工资低且不稳定。而外部就业市场竞争日益激烈，对劳动力技能要求却在不断提升。这 使务工型农户的家庭生计状况面临着威胁，影响着家庭金融资本及物质资本的拓展。传 统务农型农户虽然拥有相对最高的自然资本储量，但其他四项生计资本均处于最低水 平，尤其是金融资本低更至 0.087 。实际上，该类型农户并不具备选择及其他生计策略的 能力和资本, 他们只能依赖大面积的耕种获取收人, 但由于研究区处于高山地区, 受自 然地理、气候条件等不可控因素影响, 土地耕种质量有限且面临灾害风险, 加上市场菜 价的波动，传统农户生计呈现出极大的脆弱性和不稳定性。

\section{3 农户生计策略类型及生计资本的空间形态}

依据各调研农户所在地的邻接拓扑关系, 运用 ArcGIS 10.2 计算得出研究区农户生计 策略类型及生计资本值的全局 Moran's I指数，具体结果如表 5:

由表可知, 研究区农户生计策略类型的全局 Moran's $I$ 指数均大于 0 , 且 $Z$ 得分大于 $1.96, P$ 值小于 0.05 , 通过显著性检验。这表明不同类型的农户在空间上的分布具有正向 自相关性, 在研究区呈现显著的集簇分布。而农户生计资本总值的 $Z$ 得分和 $P$ 值均未通 过显著性检验，表明其在研究区内呈现较随机的分布格局，农户生计资本总值在空间分 布上的相似性较弱。这一结果与实际调研情况较为符合。

表 5 农户生计策略类型及生计资本值的空间自相关结果

Table 5 Spatial autocorrelation results of households' livelihood strategy types and livelihood capital value

\begin{tabular}{ccccccc}
\hline 自相关指标 & Moran's $I$ & $E(I)$ & 方差 & Z得分 & 阈值 $(\alpha=0.05)$ & $P$ 值 \\
\hline 农户生计策略类型 & 0.2177 & -0.0062 & 0.0024 & 4.5734 & 1.96 & 0.0000 \\
农户生计资本值 & 0.0694 & -0.0062 & 0.0023 & 1.5474 & 1.96 & 0.1217 \\
\hline
\end{tabular}


在研究区，从事旅游主营型和均衡兼收型的农户主要聚集分布在以旅游接待功能为 主的古镇社区、共和村旅游沿线片区和柏秧坪村温泉片区，而传统务农型和务工型农户 主要分布在上述片区中距离交通干线更远的地方或以蔬菜、果树种植为主的蔡阳坪村、 金光村等。而拥有不同生计资本值的农户在空间上分布较为随机，相邻农户间的生计资 本存在差异。

\section{4 农户生计策略转化的影响因素分析}

为了更好地揭示研究区低水平生计策略农户向高水平生计策略农户转化的规律和路 径, 本文以生计脆弱性最高的传统务农型农户和务工型农户为参照标准, 探究影响这两 类农户向旅游主营型、均衡兼收型生计策略转化的关键影响因素及影响程度。根据多元 Logistic 回归的检验结果, 模型似然比检验的卡方值 $=279.956$, 自由度 $\mathrm{d} f=40$, 伪决定系 数 $=0.862$, 模型整体在 0.00 水平显著，模型拟合效果好，回归结果见表 6 。

表 6 农户生计资本、空间要素与生计策略的多元 logistic 回归分析

Table 6 Multiple logistic regression of livelihood capital, geographical elements and livelihood strategies

\begin{tabular}{|c|c|c|c|c|c|}
\hline \multirow{3}{*}{ 较高水平生计策略 } & \multirow{3}{*}{ 主要影响因素 } & \multicolumn{2}{|c|}{ 以传统务农型为参考 } & \multicolumn{2}{|c|}{ 以务工型为参考 } \\
\hline & & 回归系数 & 敏感性 & 回归系数 & 敏感性 \\
\hline & & $B$ & $\operatorname{Exp}(B)$ & $B$ & $\operatorname{Exp}(B)$ \\
\hline \multirow[t]{6}{*}{ 旅游主营型 } & 物资资本 & $15.737^{* * *}$ & $6.83 \mathrm{E}+06$ & $10.051^{* *}$ & $2.32 \mathrm{E}+04$ \\
\hline & 社会资本 & $2.174^{* *}$ & 8.795 & $3.684^{* *}$ & 39.820 \\
\hline & 海拔高度 & $-21.132^{* * * *}$ & $6.64 \mathrm{E}-10$ & $-16.471^{* * *}$ & $7.03 \mathrm{E}-08$ \\
\hline & 景点距离 & $-40.506^{* * * *}$ & $1.00 \mathrm{E}-13$ & $-36.232^{* * *}$ & $1.00 \mathrm{E}-13$ \\
\hline & 公路距离 & $-46.272^{* * * *}$ & $1.00 \mathrm{E}-13$ & $-39.521^{* * *}$ & $1.00 \mathrm{E}-13$ \\
\hline & 常数项 & $26.707^{* * *}$ & - & $22.629^{* * *}$ & - \\
\hline \multirow[t]{5}{*}{ 均衡兼收型 } & 金融资本 & $25.472^{* * *}$ & $1.15 \mathrm{E}+11$ & $10.121^{* * * *}$ & $2.49 \mathrm{E}+04$ \\
\hline & 海拔高度 & $-18.311^{* * *}$ & $1.12 \mathrm{E}-08$ & $-13.65^{* * *}$ & $1.18 \mathrm{E}-06$ \\
\hline & 景点距离 & $-32.272^{* * *}$ & $1.10 \mathrm{E}-13$ & $-27.997^{* * *}$ & $7.93 \mathrm{E}-13$ \\
\hline & 公路距离 & $-46.477^{* * * *}$ & $1.00 \mathrm{E}-13$ & $-39.726^{* * *}$ & $1.00 \mathrm{E}-13$ \\
\hline & 常数项 & $17.863^{* * *}$ & - & $13.785^{* *}$ & - \\
\hline
\end{tabular}

注: * ***和**分别在 $0.1 、 0.05$ 和 0.01 上显著。

从影响农户生计策略选择的生计资本因素来看，物质资本和社会资本对传统务农型 农户和务工型农户选择旅游主营型生计策略有显著的积极影响。物质资本每增加一个单 位, 在其他解释变量不变的情况下，传统务农型农户和务工型农户选择旅游主营型生计 策略的概率将扩大为原来的 $6.83 \times 10^{6}$ 和 $2.32 \times 10^{4}$ 倍。社会资本每增加一个单位，传统务农 型农户和务工型农户选择旅游主营型生计策略的概率将扩大为原来的 8.795 倍和 39.82 倍。这表明，房屋、耐用消费品等物质资本以及技能培训机会等社会资本越丰富，越有 利于低水平生计农户选择旅游主营型生计策略。

金融资本对两类脆弱性农户选择均衡兼收型生计策略有显著的积极影响。金融资本 每增加一个单位，在其他自变量不变的情况下，传统务农型农户和务工型农户选择均衡 兼收型生计策略的概率将扩大为原来的 $1.15 \times 10^{11}$ 倍、 $2.49 \times 10^{4}$ 倍。这表明，两类低水平 生计型农户拥有的家庭现金收人、借贷款等金融资本越多, 越有利于他们采取均衡兼收 型生计策略。 
从影响农户生计策略转化的地理因素来看，居民家庭所处的海拔高度、距海螺沟核 心景点的距离、距公路的距离都对低水平农户选择高水平生计策略有显著的影响。由于 这三类地理要素经回归后的待估参数为负，这说明，海拔高度、核心景点距离和公路距 离对农户选择高水平生计有负向影响。海拔高度越低、距离核心景点和公路的距离越 近，越有利于他们选择均衡兼收型和旅游主营型生计策略。

结合研究区农户居住点的空间分布特征来看（图 3)，生计资本值最高的均衡兼收型 和旅游主营型农户，主要分布在距离景区核心旅游资源最近的村落或靠近旅游观光干道 与旅游接待区，利用原址改建的房屋进行旅游接待活动或其他商贸活动。而生计资本值 最低的传统务农型农户，却主要分布在海拔较高、偏离旅游交通干线的位置，导致该类 农户既缺少开展高生计策略的交通位置和旅游资源优势, 又因生计资本的缺乏而长期面 临贫困的弱势地位。

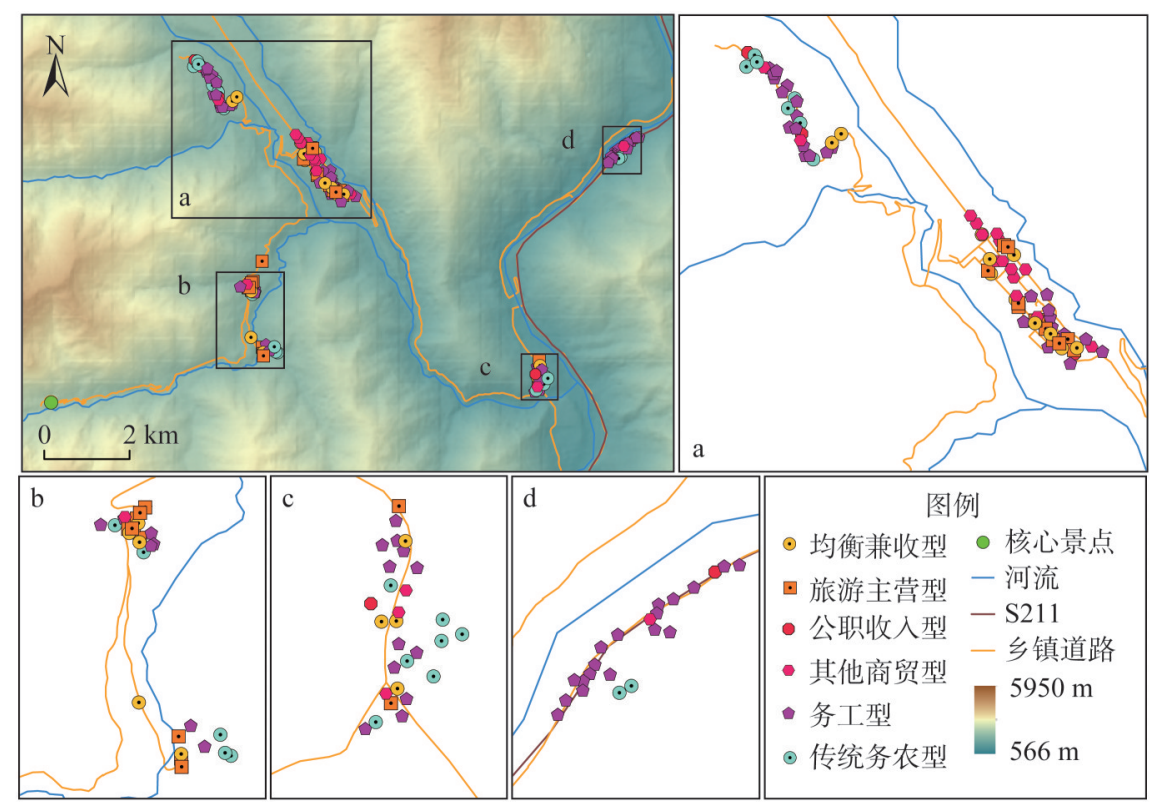

图 3 六类农户居民点的空间分布

Fig. 3 Spatial distribution of six types of farmer residential areas

\section{3 结论与讨论}

\section{1 结论}

海螺沟景区周边村落的居民主要以传统务农型、务工型、公职收人型、其他商贸 型、旅游主营型、均衡兼收型为主要类型的六种生计策略为主。以均衡兼收型和旅游主 营型为主要生计策略的农户是研究区可持续生计水平最高的农户，而以传统务农型和务 工型为主要生计策略的农户其生计资本水平最差，面临着诸多生计风险威胁。选择各类 型策略的农户其生计资本值由高到低依次为： $T e$ 均衡兼收型（2.158）> $T c$ 旅游主营型 （1.872）>Th 公职收人型（1.420）> Td 其他商贸型（1.381）> Tb 务工型（1.353）> Ta传统 务农型 (1.055)。

金融资本是影响研究区传统务农型农户和务工型农户选择均衡兼收型生计策略的显 
著性因素; 物质资本和社会资本是影响传统务农型农户和务工型农户选择旅游主营型生 计策略的显著性因素; 海螺沟景区农户所处的海拔高度、距离核心景点和公路的距离对 农户选择高水平生计策略也有着重要的影响。居住地的海拔越低，离旅游景点、公路越近 的农户，选择均衡兼收型、旅游主营型这两类高水平生计策略的可能性越大。在空间上， 均衡兼收型和旅游主营型农户主要分布在核心旅游景区、旅游接待区及旅游主干道附近, 而传统务农型和务工型农户主要分布在高海拔的农业耕作区或偏离交通旅游干线的区域。

\section{2 讨论}

在已有农户生计资本与生计策略的研究中, 农户生计策略被普遍划分为 “纯农型” “农兼型” 和 “非农型” 三类 ${ }^{[13-16]}$, 而本文结合旅游地的实际情况, 将非农型生计策略细 分为 “务工型” “公职收人型” “旅游主营型” “其他商贸型” 和 “均衡兼收型”, 并对每 类农户的生计资本状况进行了测算。这将更有利于精准地识别不同脆弱性程度的农户特 征及其短缺资本与优势资本，为政府改善民生、制定更可持续的生计发展政策提供参考。

从生计资本对生计策略的影响来看, 本文的研究结果也验证了前人研究中提出的一 些结论, 但在物质资本方面, 与以往研究提出的 “物质资本存量较大的农户倾向从事农 业生计活动” 不太一致的是 ${ }^{[20]}$, 本文发现研究区物质资本存量较多的农户更倾向于选择 旅游主营型这类非农生计策略。从旅游主营策略的特征来看, 这可能是源于该生计策略 对房屋门面、电视机、空调、汽车、摄像机等物质资本的需求比现阶段务农型户对农机 具等物质资本的需求更大。此外, 本文在已有研究基础上补充了农户生计策略的空间分 布特征及空间距离、海拔要素对生计策略选择的影响。研究结论有利于政府重视居民点 空间布局对改善农户生计状况的作用。

根据研究结果, 本文发现以种养殖和打工为主要生计活动的传统务农型和务工型农 户是海螺沟景区目前生计状况最差的两类农户, 实际上, 这些农户也是海螺沟景区打赢 脱贫攻坚战，樂牢民生底线、实现地区经济发展最需要关注的一类人群。由于物质资 本、社会资本和金融资本的缺乏限制了这些脆弱性农户选择其他多样化的高水平的生计 策略, 地理区位阻碍了他们获得更好的生计活动机会。因此在今后的政策制定和旅游发 展规划中，相关部门可以采取以下建议:

加强海螺沟景区金融资本建设，促进农村信贷服务多元化。政府需要不断完善农村 信贷机制和农业补贴政策，通过鼓励发展多层次的农村金融机构和非金融机构，为脆弱 性农户提供小额贷款、低息和占息贷款，使他们能够有机会选择多样化的生计策略并扩 大经营规模。

通过搬迁或合理的旅游布局规划，改善居住地的区位条件。政府及相关部门应努力 把脆弱性农户纳人低海拔的居民聚集区和交通干线中来，或通过深人挖掘并打造新的旅 游景点及外部休闲产品 ${ }^{\left[{ }^{[1]}\right.}$, 让原来远离核心景点的农户有机会参与到旅游服务和经营 中，摆脱地理区位的制约，更好地发展多样化生计活动。

推动生计脆弱性农户聚集地的物质资本和社会资本建设。脆弱性农户若要选择旅游 主营型策略，则需要在获得金融资本的支持下扩建房屋或购置更多的物质设备。对于政 府而言, 则应当加快推进蔡阳坪村、金光村的沿线房屋修缮和则所改造等公共基础设施 建设, 提高当地旅游服务接待设施水平。此外, 进一步培育多样化的农村合作组织或互 联网平台、提供更多更有效的旅游服务技能和素质培训并鼓励脆弱性农户参与，则是政 府在促进当地社会资本建设中不可忽视的重要环节。 
总体看来，目前海螺沟景区的生计资本水平整体处于较低水平，大部分农户对旅游 这类高水平生计活动的参与度还不够高，这与生计资本限制有关；另一方面，可持续生 计框架下的外部生计环境、政府政策措施以及原有生计活动的结果输出也对农户生计策 略的选择有着不可忽视的影响。后续的研究可以对生计策略的影响机制进行更全面的考 虑。此外，随着时间和区域的变化，旅游地农户的生计策略的具体影响因素也可能发生 改变。因而获取面板数据，对农户生计策略进行时空差异和动态模拟演化研究，将是未 来的一个可行方向。

\section{参考文献(References):}

[1] SPENCELEY A, MEYER D. Tourism and poverty reduction: Theory and practice in less economically developed countries. Journal of Sustainable Tourism, 2012, 20(3): 297-317.

[2] 邓小海, 曾亮, 罗明义, 等. 云南乌蒙山片区所属县旅游扶贫效应分析. 生态经济, 2015, 31(2): 134-138. [DENG X H, ZENG L, LUO M Y, et al. Effects analysis of pro-poor tourism in Yunnan Wumeng mountain areas. Ecological Economy, 2015, 31(2): 134-138.]

[3] 黄细嘉, 赵晓迪. 旅游型乡村建设要素与乡村振兴战略要义. 旅游学刊, 2018, 33(7): 5-6. [HUANG X J, ZHAO X D. Elements of tourism-oriented rural construction and strategic importance of rural revitalization. Tourism Tribune, 2018, 33(7): 5-6.]

[4] 王新歌, 席建超. 大连金石滩旅游度假区当地居民生计转型研究. 资源科学, 2015, 37(12): 2404-2413. [WANG X G, XI J C. Study on livelihood transition of local residents in the tourist resort area of Jinshitan, Dalian. Resources Science, 2015, 37(12): 2404-2413.]

[5] 贺爱琳, 杨新军, 陈佳, 等. 乡村旅游发展对农户生计的影响: 以秦岭北麓乡村旅游地为例. 经济地理, 2014, 34(12): 174-181. [HE A L, YANG X J, CHEN J, et al. Impact of rural tourism development on farmer's livelihoods: A case study of rural tourism destinations in northern slope of Qinling Mountains. Economic Geography, 2014, 34(12): 174-181.]

[6] CHAMBERS R, CONWAY G R. Sustainable rural livelihoods: Practical concepts for the $21^{\text {st }}$ century. Brighton: Institute of Development Studies, 1992.

[7] DAVIES J, WHITE J, WRIGHT A, et al. Applying the sustainable livelihoods approach in Australian desert aboriginal development. The Rangeland Journal, 2008, 30(1): 55-65.

[8] NIELSEN O J, RAYAMAJHI S, UBERHUAGA P, et al. Quantifying rural livelihood strategies in developing countries using an activity choice approach. Agricultural Economics, 2013, 44(1): 57-71.

[9] ROBERTS M G, 杨国安. 可持续发展研究方法国际进展: 脆弱性分析方法与可持续生计方法比较. 地理科学进展, 2003, 22(1): 11-21. [ROBERTS M G, YANG G A. The international progress of sustainable development research: A comparison of vulnerability analysis and the sustainable livelihoods approach. Progress Geography, 2003, 22(1): 11-21.]

[10] DFID. Sustainable livelihoods guidance Sheets. London: Department for International Development, 1999.

[11] 道日娜. 农牧交错区域农户生计资本与生计策略关系研究: 以内蒙古东部四个旗为例. 中国人口·资源与环境, 2014, 24(5): 274-278. [DAO R N. Relationship between livelihood assets and livelihood strategies of rural households of farming-pastoral area: A case study on four counties in the eastern Inner Mongolia. China Population, Resources and Environment, 2014, 24(5): 274-278.]

[12] MUSHONGAH J, SCOONES I. Livelihood change in rural Zimbabwe over 20 years. Journal of Development Studies, 2012, 48(9): 1-17.

[13] 赵文娟, 杨世龙, 王潇. 基于 Logistic 回归模型的生计资本与生计策略研究: 以云南新平县干热河谷傣族地区为例. 资源科学, 2016, 38(1): 136-143. [ZHAO W J, YANG S L, WANG X. The relationship between livelihood capital and livelihood strategy based on logistic regression model in Xinping county of Yuanjiang dry-hot valley. Resources Science, 2016, 38(1): 136-143.]

[14] 苏芳, 蒲欣冬, 徐中民, 等. 生计资本与生计策略关系研究: 以张掖市甘州区为例. 中国人口·资源与环境, 2009,19 (6): 119-125. [SU F, PU X D, XU Z M, et al. Analysis about the relationship between livelihood capital and livelihood strategies: Take Ganzhou in Zhangye city as an example. China Population, Resources and Environment, 2009, 19(6): 119-125.]

[15] 江进德, 赵雪雁, 张丽, 等. 农户对替代生计的选择及其影响因素分析: 以甘南黄河水源补给区为例. 自然资源学 
报, 2012, 27(4): 552-564. [JIANG J D, ZHAO X Y, ZHANG L, et al. Study on alternative livelihood choice and the factors affecting livelihoods choice: A case of the yellow river water supply area of Gannan. Journal of Natural Resources, 2012, 27(4): 552-564.]

[16] 徐定德, 张继飞, 刘郡权, 等. 西南典型山区农户生计资本与生计策略关系研究. 西南大学学报, 2015, 37(9): 118126. [XU D D, ZHANG J F, LIU S Q, et al. An analysis of the relationship between livelihood capital and livelihood strategies of the typical mountainous settlements in southwestern China. Journal of Southwest University, 2015, 37(9): 118-126.]

[17] 王亚茹, 赵雪雁, 张钦, 等. 高寒生态脆弱区农户的气候变化适应策略评价: 以甘南高原为例. 地理研究, 2017, 35 (7): 1273-1287. [WANG Y R, ZHAO X Y, ZHANG Q, et al. Farmers' climate change adaptation strategies in an ecologically vulnerable alpine region: A case of Gannan Plateau. Geographical Research, 2017, 35(7): 1273-1287.]

[18] 王凯, 李志苗, 易静. 生态移民户与非移民户的生计对比: 以遗产旅游地武陵源为例. 资源科学, 2016, 38(8): 16211633. [WANG K, LI Z M, YI J. Contrasting the livelihoods of immigrants and nonimmigrants in the Wulingyuan world heritage area. Resources Science, 2016, 38(8): 1621-1633.]

[19] 张海盈, 姚娟, 马娟. 生计资本与参与旅游业牧民生计策略关系研究: 以新疆喀纳斯生态旅游景区为例. 旅游论坛, 2013, 6(4): 40-44. [ZHANG H Y, YAO J, MA J. Livelihood capital and participation in the tourism industry herdsmen and the livelihood of relation strategy: A case of Kanas ecological tourism scenic area in Xinjiang. Tourism Forum, 2013, 6(4): 40-44.]

[20] 孙博, 刘倩倩, 王昌海, 等. 农户生计研究综述. 林业经济, 2016, (4): 49-53. [SUN B, LIU Q Q, WANG C H, et al. Review on household livelihood in China. Forestry Economics, 2016, (4): 49-53.]

[21] 阎建忠, 吴莹芗, 张镱锂, 等. 青藏高原东部样带农牧民生计的多样化. 地理学报, 2009, 64(2): 221-233. [YAN J Z, WU Y Y, ZHANG Y L, et al. Livelihood diversification of peasants and nomads of eastern transect in Tibetan Plateau. Acta Geographica Sinica, 2009, 64(2): 221-233.]

[22] 何仁伟, 刘邵权, 刘运伟, 等. 典型山区农户生计资本评价及其空间格局: 以四川省凉山彝族自治州为例. 山地学 报, 2014, 32(6): 641-651. [HE R W, LIU S Q, LIU Y W, et al. Evaluation and spatial distribution of farmer's livelihood capital in representative mountain areas: A case study of Liangshan Yi autonomous prefecture of Sichuan, China. Mountain Research, 2014, 32(6): 641-651.]

[23] CAMPBELL B M, SAYER J A, FROST P, et al. Assessing the performance of natural resource systems. Ecology Society, 2001, 5(2): 286-313.

[24] 史玉, 李建军. 乡村旅游多功能发展与农村可持续生计协同研究. 旅游学刊, 2018, 33(2): 15-26. [SHI Y, LI J J. The multifunctional development of rural tourism and the rural sustainable livelihood: A collaborative study. Tourism Tribune, 2018, 33(2): 15-26.]

[25] 孙特生, 胡晓慧. 基于农牧民生计资本的干旱区草地适应性管理: 以准噶尔北部的富蕴县为例. 自然资源学报, 2018, 33(5): 43-56. [SUN T S, HU X H. Grassland adaptive management in arid region based on livelihood capitals of peasants and herdsmen: A case study of Fuyun county in the north of Junggar Basin, China. Journal of Natural Resources, 2018, 33(5): 43-56.]

[26] 陈佳, 张丽琼, 杨新军, 等. 乡村旅游开发对农户生计和社区旅游效应的影响: 旅游开发模式视角的案例实证. 地理 研究, 2017, 36(9): 1709-1724. [CHEN J, ZHANG L Q, YANG X J, et al. The impact of tourism development on changes of households' livelihood and community tourism effect: A case study based on the perspective of tourism development mode. Geographical Research, 2017, 36(9): 1709-1724.]

[27] AVILA-FOUCAT V S, RODRÍGUEZ-ROBAYO K J. Determinants of livelihood diversification: The case wildlife tourism in four coastal communities in Oaxaca, Mexico. Tourism Management, 2018, 69: 223-231.]

[28] 任平, 洪步庭, 周介铭. 基于空间自相关模型的农村居民点时空演变格局与特征研究. 长江流域资源与环境, 2015, 24(12): 1993-2002. [REN P, HONG B T, ZHOU J M. Research of spatio-temporal pattern and characteristics for the evolution of rural settlements based on spatial autocorrelation model. Resources and Environment in the Yangtze Basin, 2015, 24(12): 1993-2002.]

[29] 周成, 金川, 赵彪, 等. 区域经济一生态一旅游耦合协调发展省际空间差异研究. 干旱区资源与环境, 2016, 30(7): 203-208. [ZHOU C, JIN C, ZHAO B, et al. The provincial difference of coupling coordinative development of regional economy-ecology-tourism. Journal of Arid Land Resources and Environment, 2016, 30(7): 203-208.]

[30] 李小云, 董强, 饶小龙, 等. 农户脆弱性分析方法及其本土化应用. 中国农村经济, 2007, (4): 32-39. [LI X Y, DONG 
Q, RAO X L, et al. Analysis method of farmer vulnerability and its localization application. Chinese Rural Economy, 2007, (4): 32-39].

[31] 杨忍, 文琦, 王成, 等. 新时代中国乡村振兴:探索与思考: 乡村地理青年学者笔谈. 自然资源学报, 2019, 34(4):890910. [YANG R, WEN Q, WANG C, et al. Discussions and thoughts of the path to China's rural revitalization in the new era: Notes of the young rural geography scholars. Journal of Natural Resources, 2019, 34(4): 890-910.]

\title{
The evaluation of households' livelihood capital and their livelihood strategies in the tourist area:
}

\author{
A case study in Hailuogou Scenic Area
}

\author{
LIU Jun, ZHANG Heng-jin, JIN Meng-meng, LI Ning-xin \\ (Tourism School, Sihuan University, Chengdu 610065, China)
}

\begin{abstract}
Sustainable development of tourist destinations needs to focus on the sustainable livelihood of local residents. Based on the theory of sustainable livelihood, this paper takes Hailuogou Scenic Area as an example to analyze the livelihood capital, spatial distribution characteristics of local households and the main factors affecting the traditional and labororiented households' livelihood strategies. Firstly, through the household surveys and interviews, farmers in Hailuogou scenic spot are divided into six types according to their income sources and the direction of their main labor input. Secondly, according to the framework of livelihood capital evaluation and index weight, the sustainable livelihood conditions of local households are quantitatively analyzed. Then, with the multiple logistic regression model, the study identifies the main factors that affect the households' choice of high-level livelihood strategies and reveals the spatial distribution characteristics of different types of households. The results show that among the six livelihood strategies chosen by rural households in Hailuogou Scenic Area, balanced-income and tourism-oriented households have the highest level of sustainable livelihood. On the contrary, traditional and labor-oriented households, who are facing many livelihood risks, have the lowest level of livelihood capital. Besides, local households with different livelihood strategies are clustered and distributed spatially. Financial capital is the significant factor affecting the traditional and labor-oriented households' choice of balanced-income strategy, while material capital and social capital have a significant positive effect on the two types of low-level livelihood farmers' choice of tourismoriented livelihood strategy. In addition, the elevation of rural residential areas, the distance from tourist attractions and roads also have an important impact on farmers' choice of strategies, which means that the lower the elevation of the residential area, the more likely the farmers will choose the balanced-income and tourism-oriented strategies. Similarly, the closer to the core tourist attractions and highways, the more likely local households are to choose two kinds of high-level livelihood strategies.
\end{abstract}

Keywords: sustainable livelihoods; spatial autocorrelation; multiple logistic regression; Hailuogou Scenic Area 